\title{
Larval development of the pea crab Afropinnotheres monodi Manning, 1993 (Decapoda, Pinnotheridae) using plankton-collected and laboratory-reared specimens: effects of temperature
}

\author{
Elena Marco-Herrero ${ }^{a}$, Pilar Drake ${ }^{a}$, J. Ignacio González-Gordillo ${ }^{b}$ and Jose A. Cuesta ${ }^{a}$

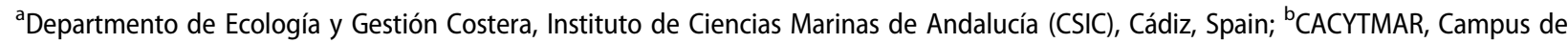 \\ Excelencia Internacional del Mar, Universidad de Cádiz, Cádiz, Spain
}

\begin{abstract}
The aim of this study was to assess the effect of temperature on the survival and duration of larval development in the African pea crab Afropinnotheres monodi, as well as to describe its larval stages. We studied larvae reared in the laboratory and also specimens collected from plankton from the Gulf of Cádiz at two different temperatures. According to the results of this study, larval development of $A$. monodi involves four zoea stages and one megalopa and lasts around 25 days at $25^{\circ} \mathrm{C}$, and longer than 40 days at $19^{\circ} \mathrm{C}$. Such a temperature-related duration of this dispersive phase may be causing a higher recruitment to parental populations during the summer, but a higher dispersal to new locations during the rest of the year, a seasonal pattern of dispersion which could favour the successful expansion of this non-native species into European waters. The identification of both larval phases from plankton samples and adult specimens was carried out using morphological characters and molecular techniques. Both the 16S mtDNA sequences of this species, now available in GenBank, and the larval descriptions provided by this study could help to establish an early alert for the detection of this African species in its northward expansion.
\end{abstract}

ARTICLE HISTORY

Received 15 December 2014

Accepted 17 July 2015

Published online 25

November 2015

\section{RESPONSIBLE EDITOR}

Matz Berggren

\section{KEYWORDS}

Afropinnotheres monodi; megalopa; morphology; Pinnotheridae;

temperature effects; zoea; 16Smt DNA

\section{Introduction}

Pinnotheridae De Haan, 1833 is a brachyuran family comprised of small symbiotic crabs. Due to their small size and symbiotic lifestyle, little is known about their life history, reproductive traits, larval development and systematics (Palacios-Theil et al. 2009; Becker \& Türkay 2010). Recent molecular studies have reduced the number of genera so far attributed to the subfamily Pinnotherinae sensu stricto De Haan, 1833 to only 25, with 152 species (Palacios-Theil et al. 2009). Known species of this subfamily are characterized by a typical trilobated telson in the zoea stages. There are only larval data for eight of its genera, namely Afropinnotheres Manning, 1993, Buergeres Ng \& Manning, 2003, Gemmotheres E. Campos, 1996, Nepinnotheres Manning, 1993, Orthotheres Sakai, 1969, Ostracotheres H. Milne Edwards, 1853, Pinnotheres Bosc, 1802 and Zaops Rathbun, 1900.

Afropinnotheres monodi Manning, 1993 is an African pea crab that recently arrived on southwestern European coasts, having been reported from several localities in the Gulf of Cádiz and south of Portugal (Subida et al. 2011). Until then, this small pinnotherid crab had a recorded distribution restricted to four localities, two in Morocco and two in Mauritania, but with no data on their hosts (Manning 1993). The populations inhabiting the Gulf of Cádiz have now been studied, and data are available on their hosts as well as on the period of reproduction (Drake et al. 2014). Afropinnotheres monodi has a large number of bivalve hosts, and has been collected with varying degrees of prevalence from Scrobicularia plana (da Costa, 1778), Cerastoderma glaucum (Bruguière, 1789), Chamelea gallina (Linnaeus, 1758), Donax trunculus Linnaeus, 1758, Mactra stultorum (Linnaeus, 1758), Spisula solida (Linnaeus, 1758), Ruditapes decussatus (Linnaeus, 1758) and the mussel Mytilus galloprovincialis Lamarck, 1819, in which the ovigerous females reach a larger size and therefore have a higher number of eggs (Drake et al. 2014). In a similar way to other species originating from Africa, A. monodi reproduce throughout the year, although the lowest number of ovigerous females was observed in the autumn and zoea stage I in the winter (Drake et al. 1998). This long reproductive period, together with its wide range of host species, offers a clear advantage for successful establishment and

CONTACT Elena Marco-Herrero elena.marco@csic.es Departamento de Ecología y Gestión Costera, Instituto de Ciencias Marinas de Andalucía, CSIC, Avenida República Saharaui, 2, 11519, Puerto Real, Cádiz, Spain 
expansion to new areas. However, the maximum distance that larvae can disperse tends to be temperature-dependent, in temperate areas with a remarkable temperature seasonal pattern (Lindley 1990; DickeyCollas et al. 2000; Pfeiffer-Hoyt \& McManus 2005).

The aim of this study was to assess the effect of temperature on the survival and on the duration of larval development for the species, as well as to describe the larval stages. This could help to determine how the number of larval stages and duration of larval development could contribute to the successful expansion of the species through European waters. Knowledge of the larval morphology could allow for the identification of the various stages found in plankton samples, and to help differentiate them from larvae of other European pea crab species. Taking into account the difficulties in pinnotherid taxonomy, especially for non-specialists, a molecular marker could also help in the identification of the larval stages of $A$. monodi.

\section{Materials and method}

\section{Plankton-collected larvae}

The estuary of the Guadalete River in the Bay of Cádiz (southwest Spain) was sampled on various periods between the late spring of 2006 and the summer of 2012. A plankton net with a mesh size of $500 \mu \mathrm{m}$ was deployed at a fixed point on the docks at the Marina of the Puerto Santa María, Cádiz, Spain (for more sampling details see Olaguer-Feliú et al. 2010). Samples were taken at intervals of $24 \mathrm{~h}$ and transported to the laboratory where decapod larval stages were sorted and fixed in ethanol (90\%) for later morphological and molecular studies.

\section{Larval cultures}

Two ovigerous females were recovered from inside the clam Scrobicularia plana in the Rio San Pedro inlet $\left(36^{\circ} 31^{\prime} \mathrm{N}, 6^{\circ} 12^{\prime} \mathrm{W}\right)$, Bay of Cádiz (southwest Spain) on 2 December 2011 and 8 May 2012. They were then placed in aquaria containing filtered and well-aerated sea water with a salinity of $32 \pm 1 \%$ o and kept at $19 \pm 2^{\circ} \mathrm{C}$ (December) and $25 \pm 2^{\circ} \mathrm{C}$ (May). A total of 311 and 417 zoeae hatched on 4 December 2011 and 17 May 2012, respectively. The 100 most actively swimming zoeae of each hatch were transferred individually to plates with six containers of 10 $\mathrm{ml}$ each, and the rest were placed in 2 litre glass bottles with aeration for mass culture. Due to the small size of all larval stages, from zoea I to megalopa, they were fed ad libitum with the rotifer Brachionus plicatilis Müller, 1787 (fed with Nannochloropsis gaditana L.M. Lubián, 1982). All larvae were maintained under the same constant conditions of temperature and salinity mentioned above for the ovigerous females. Cultures were checked for exuviae and dead larvae. Exuviae and specimens of all stages were fixed in ethanol (90\%) for later examination.

\section{Material studied from plankton samples}

A total of 62 unidentified zoeae (various stages between zoea I and IV) and 13 unidentified megalopae attributed to Pinnotheridae were collected during the period of study from the plankton of Guadalete River. Although several of these larvae were identified initially using the $16 \mathrm{~S}$ mtDNA marker, measurements and dissections were also carried out for comparison with the larvae of Afropinnotheres monodi reared in the laboratory from ovigerous females.

\section{Larval morphology and taxonomic account}

Dissections, drawings and measurements were made using the same methodology as described in previous works by the present authors (for details see MarcoHerrero et al. 2012, 2014). The long setae on the distal exopod segments of the first and second maxillipeds were drawn truncated. Descriptions and figures were arranged according to the standards proposed by Clark et al. (1998). Measurements taken in zoeal stages were: rostro-dorsal length (RDL) measured from the tip of the rostral spine to the tip of the dorsal spine; cephalothorax length $(\mathrm{CL})$ measured from the frontal margin (between the eyes) to the posterolateral cephalothoracic margin; cephalothoracic rostral spine length ( $R L$ ) measured as the distance from the base to the tip of the rostral spine; and cephalothoracic dorsal spine length $(\mathrm{DL})$ as the distance from the base to the tip of the dorsal spine. For the megalopa, cephalothorax length $(\mathrm{CL})$ measured from the frontal to the posterior margin of the cephalothorax, and cephalothorax width $(\mathrm{CW})$ as the cephalothorax maximum width.

Parental females and a series of all larval stages reared in the laboratory and plankton samples of Afropinnotheres monodi were deposited at the Instituto de Ciencias Marinas de Andalucía, Cádiz (ICMAN) crustacean collection under numbers of accession ICMAN2015-012 and ICMAN2015-013.

In the taxonomic account, the first zoeal stage is described in detail, and only the main differences in subsequent stages are also noted. 


\section{Molecular identification}

The identification of planktonic larval stages was based on partial sequences of the $16 \mathrm{~S}$ mtDNA gene. DNA extraction from larvae, polymerase chain reaction (PCR) and sequencing followed the same protocols used in previous works by the present authors (for more details see Marco-Herrero et al. 2013, 2014). The $16 \mathrm{~S} \mathrm{mtDNA}$ sequences obtained were compared with those from Iberian pinnotherid species deposited in GenBank: Pinnotheres pisum (Linnaeus, 1767) (AM180694), Nepinnotheres pinnotheres (Linnaeus, 1758) (EU935001), and a new, as yet unpublished sequence of Afropinnotheres monodi obtained in the present study. These new sequences obtained from larvae and adults of $A$. monodi were deposited in GenBank under accession numbers KT364713-KT364716.

\section{Data analysis}

The effect of water temperature on the duration of each larval stage was ascertained by carrying out one-way ANOVA tests and Student-Newman-Keuls a posteriori tests. Prior to the statistical analyses, data were log-transformed to homogenized variances. When data did not meet ANOVA assumptions, statistical differences were assessed using non-parametrical Kruskal-Wallis ANOVA tests and box and whisker plots. Differences in mortality rates related to development stage and temperature were tested by using the chi-squared test.

\section{Results}

\section{Taxonomy}

Class Malacostraca Latreille, 1802

Order Decapoda Latreille, 1802

Family Pinnotheridae De Haan, 1833

Genus Afropinnotheres Manning, 1993

Afropinnotheres Manning, 1993: 130. Type species: Afropinnotheres monodi Manning, 1993

Afropinnotheres monodi Manning, 1993

Zoea I (Figures 1A,a, 2A-C, 3A-D, 4A,B), Zoea II (Figures $1 B, 4 C$ ), Zoea III (Figures 1C, 4D), Megalopa (Figures 1E-G, 2G-I, 3H-L, 4F-J)

\section{Material examined}

Zoea I. Size: $\mathrm{RDL}=1.265 \pm 0.03 \mathrm{~mm} ; \mathrm{CL}=0.567 \pm 0.017$ $\mathrm{mm} ; \mathrm{CW}=0.786 \pm 0.019 \mathrm{~mm} ; \mathrm{RL}=0.411 \pm 0.026 \mathrm{~mm}$; $\mathrm{DL}=0.397 \pm 0.029 \mathrm{~mm} ; n=10$.
Zoea II. Size: $\mathrm{RDL}=1.733 \pm 0.17 \mathrm{~mm} ; \mathrm{CL}=0.630 \pm$ $0.013 \mathrm{~mm} ; \mathrm{CW}=1.069 \pm 0.015 \mathrm{~mm} ; \mathrm{RL}=0.592 \pm$ $0.079 \mathrm{~mm} ; \mathrm{DL}=0.613 \pm 0.056 \mathrm{~mm}, n=10$.

Zoea III. Size: $\mathrm{RDL}=2.122 \pm 0.175 \mathrm{~mm} ; \mathrm{CL}=0.831 \pm$ $0.052 \mathrm{~mm} ; \mathrm{CW}=756.5 \pm 35 \mathrm{~mm} ; \mathrm{RL}=0.709 \pm 0.063$ $\mathrm{mm} ; \mathrm{DL}=0.757 \pm 0.090 \mathrm{~mm}, n=10$.

Zoea IV. Size: $\mathrm{RDL}=2.437 \pm 0.149 \mathrm{~mm} ; \mathrm{CL}=0.917 \pm$ $0.037 \mathrm{~mm} ; \mathrm{CW}=1.380 \pm 0.103 \mathrm{~mm} ; \mathrm{RL}=0.797 \pm 0.092$ $\mathrm{mm} ; \mathrm{DL}=0.862 \pm 0.034 \mathrm{~mm}, n=10$.

Megalopa. Size: $\mathrm{CL}=0.6489 \pm 0.022 \mathrm{~mm} ; \mathrm{CW}=0.553$ $\pm 0.025 \mathrm{~mm} ; n=10$.

\section{Description}

\section{Zoea I}

Cephalothorax (Figure 1A,a): Dorsal and rostral spines straight and well developed. Lateral spines long and down-directed in typical position Pinnotheridae, close to posterior angle of ventral margin. One pair of posterodorsal and 3 pairs of anteromedian simple setae. Posterior and ventral margins without setae. Eyes sessile.

Antennule (Figure 2A): Biramous, unsegmented and conical. Endopod absent. Exopod with 3 terminal aesthetascs (2 long, 1 short), without setae.

Antenna (Figure 2B): Protopod process present as minute simple seta. Endopod present as small bud. Exopod absent.

Mandible (Figure 2C): Well-developed, incisor and molar process developed. Palp absent.

Maxillule (Figure 3A): Coxal endite with 5 plumodenticulate setae. Basial endite with 7 terminal setae (5 terminals cuspidate, 2 subterminal plumodenticulate). Endopod 2-segmented, proximal segment without setae, and with 4 terminal $(2+2)$ sparsely plumose setae on distal segment. Epipod and exopod setae absent.

Maxilla (Figure 3B): Coxal endite single-lobed, with 5-6 plumodenticulate setae. Basial endite bilobed, with $4+5$ plumodenticulate setae. Unsegmented endopod bilobed, 1 long plumodenticulate seta on proximal lobe, and 2 long plumodenticulate setae on distal lobe. Exopod (scaphognathite) with 4 plumose marginal setae plus one stout plumose process.

First maxilliped (Figure 3C): Coxa with 1 sparsely plumose seta. Basis with 10 medial sparsely plumodenticulate setae arranged as $2+2+3+3$. Endopod 5 -segmented, with 2,2,1,2,5 (1 subterminal +4 terminal) sparsely plumodenticulate setae. Exopod unsegmented, with 4 terminal plumose natatory setae.

Second maxilliped (Figure 3D): Coxa without setae. Basis with 4 sparsely plumodenticulate setae arranged $1+1+1+1$. Endopod 2-segmented, with 0,1 subterminal serrulate +4 terminal ( 2 long plumodenticulate, 2 short, 1 plumodenticulate and 1 simple) setae. 


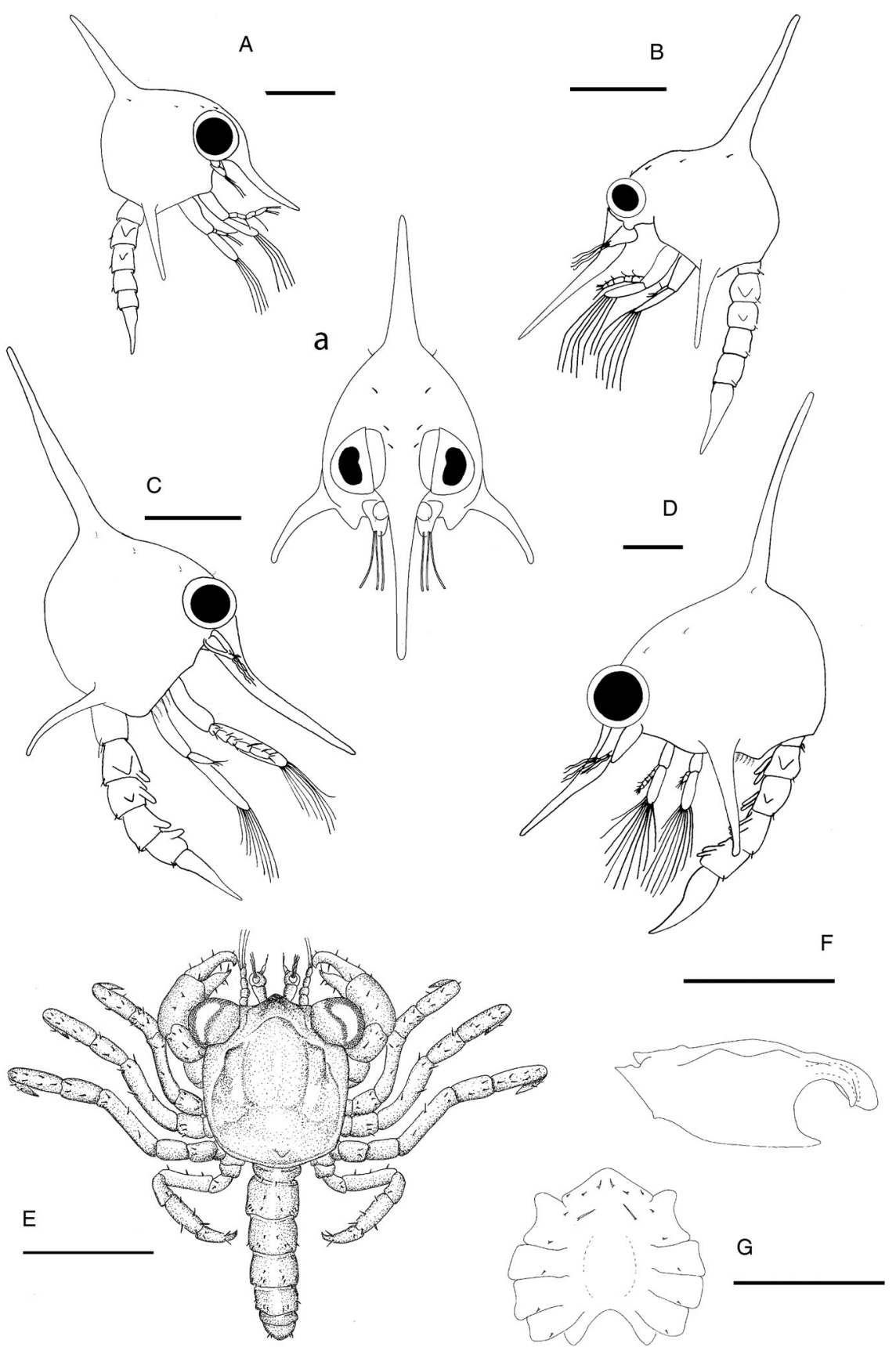

Figure 1. Afropinnotheres monodi. Lateral view: A, zoea I; B, zoea II; C, zoea III; D, zoea IV; a, frontal view of rostrum of zoea I. Megalopa: $E$, dorsal view; $F$, lateral view of carapace; $G$, sternum. Scale bars $=0.5 \mathrm{~mm}$.

Exopod unsegmented, with 4 terminal plumose natatory setae.

Third maxilliped: Absent.

Pleon (Figures 1A; 4A): 5 pleonites. Pleonite 1 without setae. Pleonites $2-5$ with a pair of minute simple setae on posterodorsal margin. Pleonite 2 with pair of forwardly directed dorsolateral processes and pleonite 3 with smaller dorsolateral processes laterally directed.

Pleopods: Absent.
Telson (Figure 4A,B): Trilobed, with 2 pairs of 3 serrulate setae on posterior margin, inner setae longest; each of lateral lobes covered with spinules distally.

\section{Zoea II}

Cephalothorax (Figure 1B): Eyes stalked and movable.

Antennule: Exopod with 4 terminal aesthetascs plus one small seta.

Antenna: Protopod process (seta) reduced in size. 

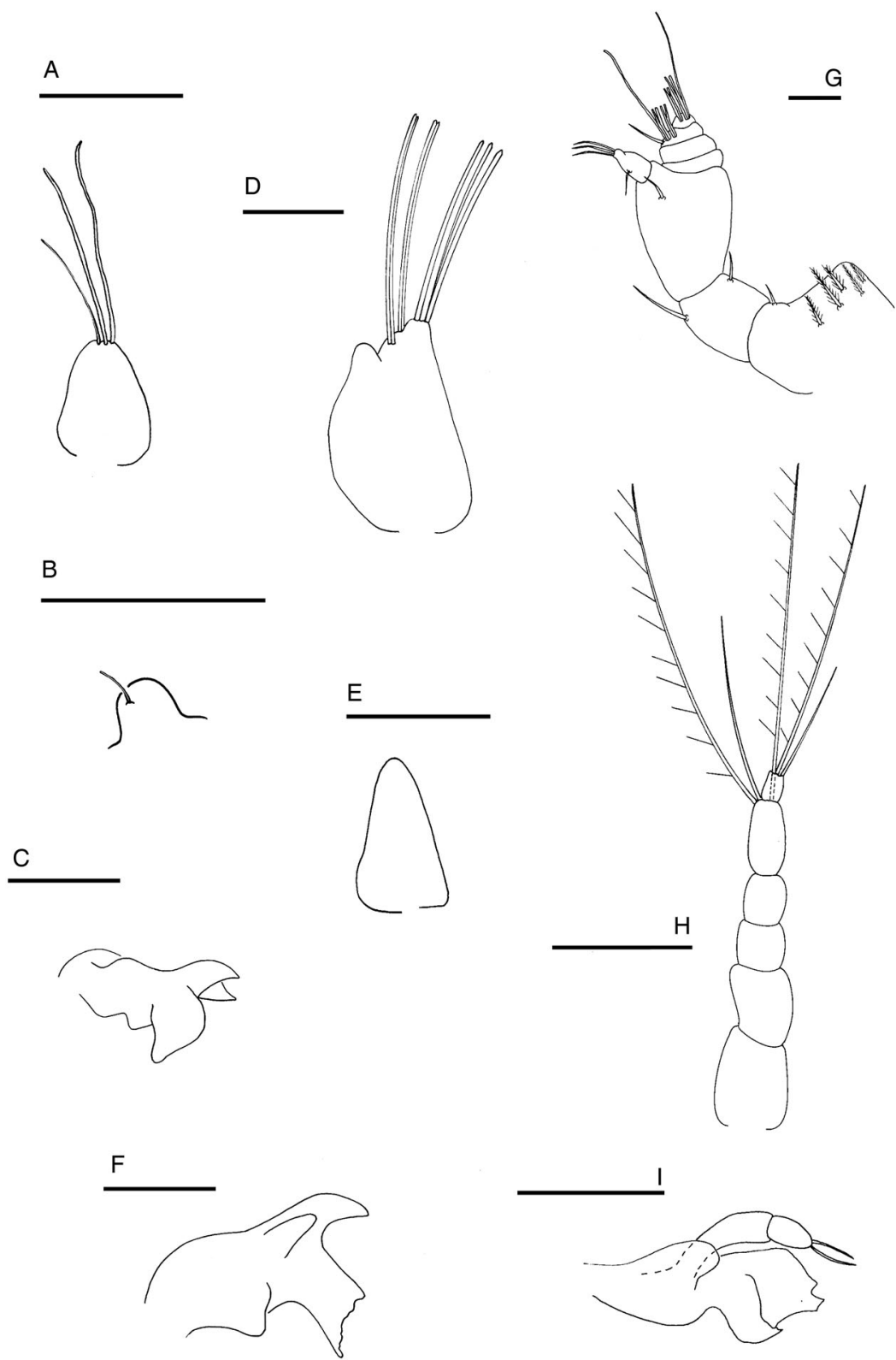

Figure 2. Afropinnotheres monodi. Antennule: A, zoea I; D, zoea IV; G, megalopa. Antenna: B, zoea l; E, zoea IV; H, megalopa. Mandible: C, zoea I; F, zoea IV; I, megalopa. Scale bars $=0.1 \mathrm{~mm}$.

Maxillule: Exopodal seta present.

Maxilla: Scaphognathite with 8 plumose marginal setae.

First maxilliped: Exopod with 6 terminal plumose natatory setae.

Second maxilliped: Exopod with 6 terminal plumose natatory setae.

Pleon (Figure 4C): Pleonite 1 with one mid-dorsal seta.

\section{Zoea III}

Cephalothorax (Figure 1C): Ventral margin with 1 highly plumose and 3 sparsely setose setae.

Antennule: Exopod with 6 aesthetascs (4 terminal and 2 subterminal).
Antenna: Protopod process absent. Endopod enlarged.

Maxillule: Coxal endite with 8 terminal plumodenticulate setae. Basial endite with 10 setae (3 subterminal plumodenticulate, 6 terminal cuspidate and 1 proximal plumose seta).

Maxilla: Basial endite with $6+5$ plumodenticulate setae. Scaphognathite with 14-15 plumose marginal setae.

First maxilliped: Exopod with 8 terminal plumose natatory setae.

Second maxilliped: Exopod with 7-8 terminal plumose natatory setae.

Third maxilliped: Present as undifferentiated buds. 

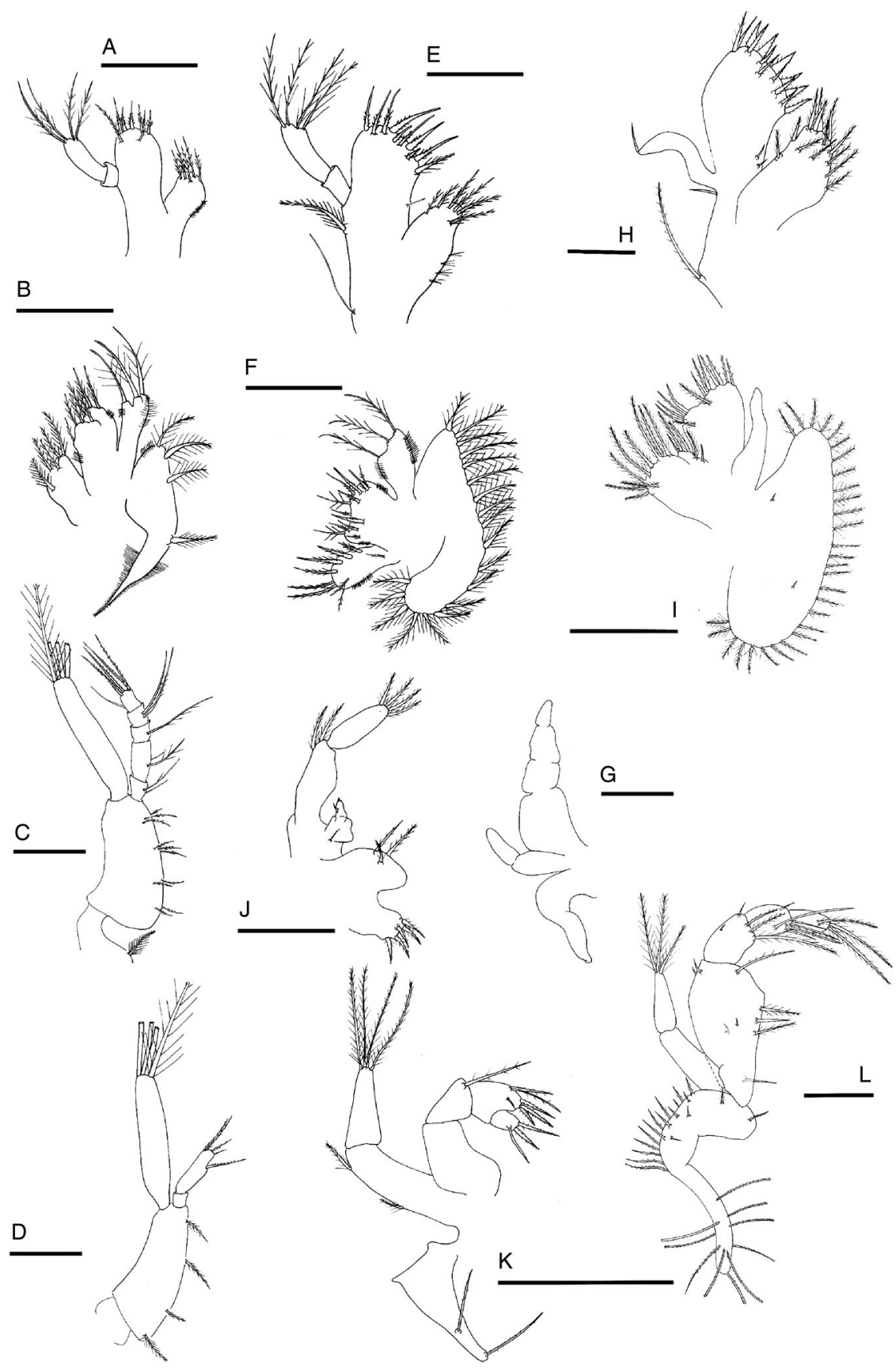

Figure 3. Afropinnotheres monodi. Maxillule: A, zoea I; E, zoea Il; H, megalopa. Maxilla: $B$, zoea I; F, zoea IV; I, megalopa. First maxilliped: C, zoea I; J, megalopa. Second maxilliped: D, zoea I; K, megalopa. Third maxilliped: G, zoea IV; L, megalopa. Scale bars = $0.1 \mathrm{~mm}$.

Pereiopods: All present as buds, slightly segmented, first pair chelate.

Pleon (Figure 4D): Pleonite 1 with 3 mid-dorsal setae.

Pleopods: Present on pleonites $2-5$ as small buds, endopods absent.

\section{Zoea IV}

Cephalothorax (Figure 1D): Ventral margin with 1 highly plumose and 4 sparsely setose setae.

Antennule (Figure 2D): Endopod bud present. Exopod with 7 aesthetascs $(2+2$ subterminal and 3 terminal).
Antenna (Figure 2E): Endopod more elongated.

Mandible (Figure 2F): Palp present as unsegmented bud without setae.

Maxillule (Figure 3E): Coxal endite with 6-7 plumodenticulate setae. Basial endite with 10-11 setae (4 subterminal plumodenticulate, 6 terminal cuspidate, 1 proximal plumose seta). Exopod and epipod setae present.

Maxilla (Figure 3F): Coxal endite with 9 plumodenticulate setae. Basial endite with $6+6$ plumodenticulate setae. Scaphognathite with 18-19 plumose marginal setae. 

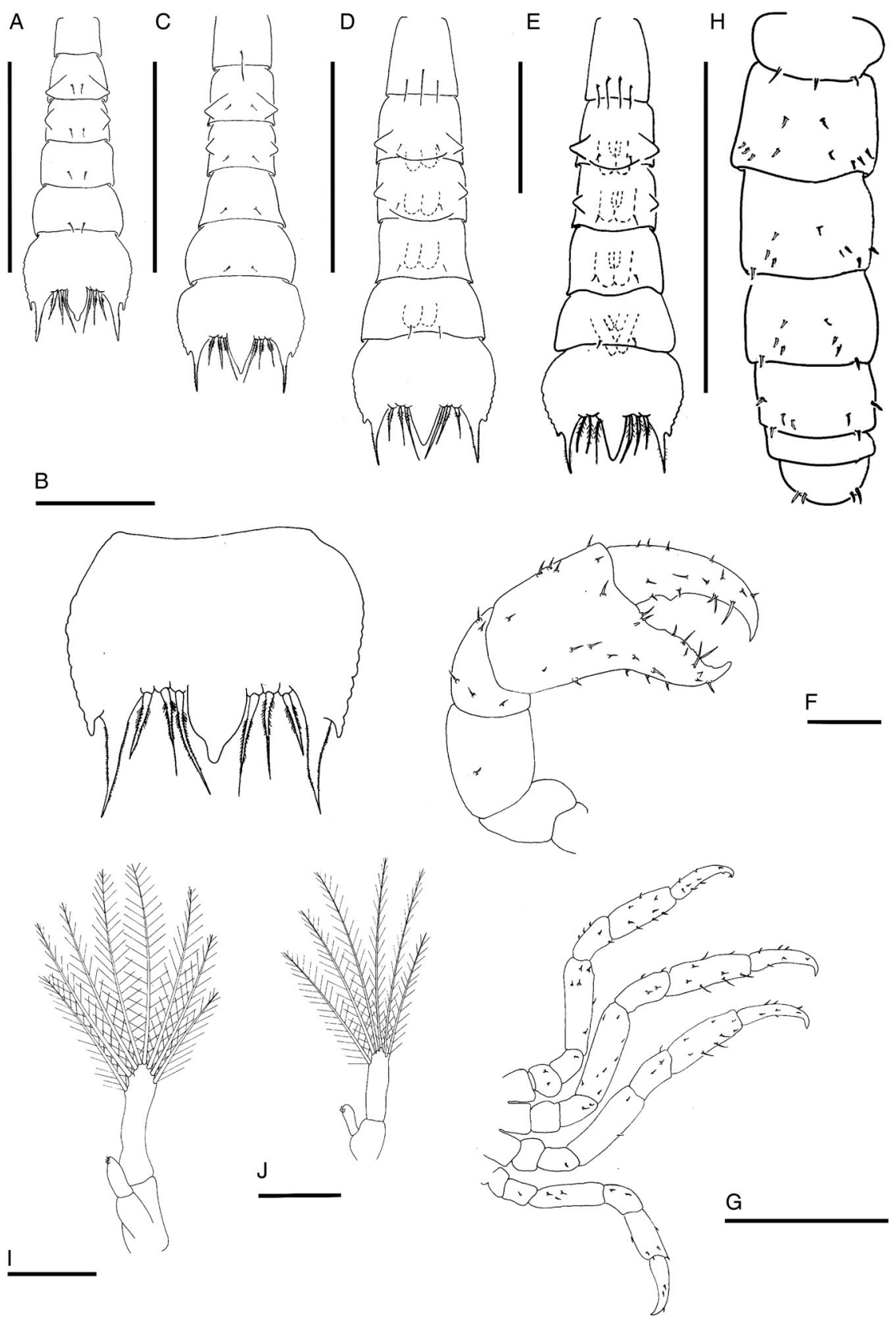

Figure 4. Afropinnotheres monodi. Abdomen, dorsal view: A, zoea I; C, zoea II; D, zoea III; E, zoea IV; $H$, megalopa. Telson: $B$, zoea I. Megalopa: F, cheliped; G, pereiopods; I, pleopods I-III; J, last pleopod. Scale bars $=0.5 \mathrm{~mm}(A, C-E, G, H), 0.1 \mathrm{~mm}(B, F, I, J)$.

First maxilliped: Coxa with 2 sparsely plumose setae. Exopod with 9 terminal plumose natatory setae.

Second maxilliped: Exopod with 9 terminal plumose natatory setae.

Third maxilliped (Figure 3G): Biramous. Endopod and exopod present as slightly segmented buds, without setae. Epipod bud present.

Pereiopods: Cheliped and pereiopods slightly segmented, without setae.

Pleon (Figure 4E): Pleonite I with 4 mid-dorsal setae.
Pleopods (Figure 4E): Biramous buds more elongate, with endopod present.

\section{Megalopa}

Cephalothorax (Figure 1E,F): Slightly longer than broad. Rostrum small, ventrally deflected (approximately $70^{\circ}$ ), with median longitudinal depression. Protogastric, cardiac and mid-posterior region with tubercles. Eyes stalked. 

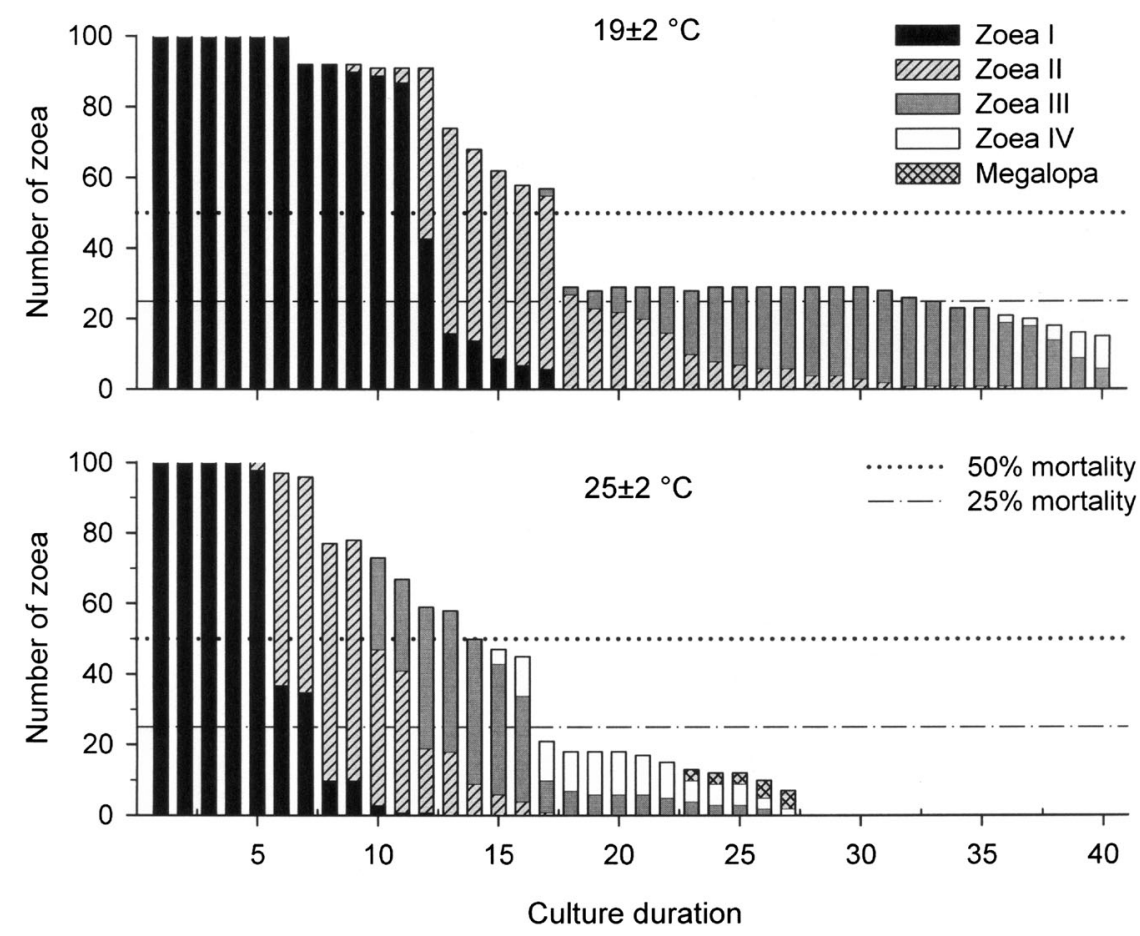

Figure 5. Mean duration (in days) of different zoeal stages of Afropinnotheres monodi reared at 19 and $25^{\circ} \mathrm{C}$.

Antennule (Figure 2G): Peduncle 3-segmented, with 6 (5 plumodenticulate, 1 simple), 2 simple, and 1 simple setae, respectively. Endopod unsegmented, with 1 basal and 3 terminal simple setae. Exopod 4-segmented, with 0,0,5,5-6 aesthetascs and 0,0,1,0 setae, respectively.

Antenna (Figure 2H): Peduncle 3-segmented, without setae and flagellum 3-segmented, with 0,3 (2 long sparsely setose, 1 long simple) and 2 (1 long sparsely setose, 1 simple) setae, respectively.

Mandible (Figure 2I): Palp 2-segmented, with 2 terminal simple setae on distal segment.

Maxillule (Figure $3 \mathrm{H}$ ): Coxal endite with 13 plumose setae. Basial endite with 2 simple setae on lower margin, 6 subterminal plumodenticulate setae and 6 terminal cuspidate setae. Endopod unsegmented, with 1 terminal seta. Exopod seta reduced to simple seta.

Maxilla (Figure 3l): Coxal endite bilobed, with $9+5$ terminal plumose setae. Basial endite bilobed, with $5+$ 8 plumodenticulate setae. Endopod unsegmented, without setae. Scaphognathite with 29-33 marginal plumose setae plus 2 small simple setae, one on each lateral surface.

First maxilliped (Figure 3J): Coxal endite with 5 plumodenticulate setae. Basial endite with 3-4 plumodenticulate terminal setae. Endopod unsegmented, with 3 simple setae. Exopod 2-segmented, with 2 terminal plumodenticulate setae on proximal segment and 4 plumose setae on distal segment.
Second maxilliped (Figure 4K): Protopod without setae. Epipodite of triangular shape, with 2 terminal long setae. Endopod 4-segmented, with 0, 1 long sparsely setose, 5 (4 plumodenticulate, 1 simple), 3 plumodenticulate setae, respectively, dactylus inserted subterminally on propodus. Exopod 2-segmented, with 1 medial and 1 subterminal simple setae on proximal segment and 4 terminal plumose setae on distal segment.

Third maxilliped (Figure 3L): Protopod with 9 plumodenticulate setae. Epipodite well-developed, with 19 proximal plumodenticulate and 10 long terminal setae. Endopod 4-segmented, ischium and merus fused, with 1 simple basal seta and 4 marginal plumodenticulate and 2 medial simple and 2 terminal simple setae, carpus with 4 ( 3 plumodenticulate, 1 simple) terminal and 1 medial simple setae, propodus with 4 (3 terminal, 1 subterminal) plumodenticulate setae, dactylus with 3 ( 2 terminal, 1 subterminal) plumodenticulate setae. Exopod 2-segmented, proximal segment without setae and 3 terminal plumose setae on distal segment.

Pereiopods (Figure 4F,G): All segments well-differentiated. Cheliped sparsely setose as shown. Pereiopods 2-5 thin and setose.

Sternum (Figure 1G): Maxillipeds and cheliped sternites fused, with 6 simple setae. Sternites of pereiopods 2-5 with $2,1,1,1$ simple setae, respectively. 


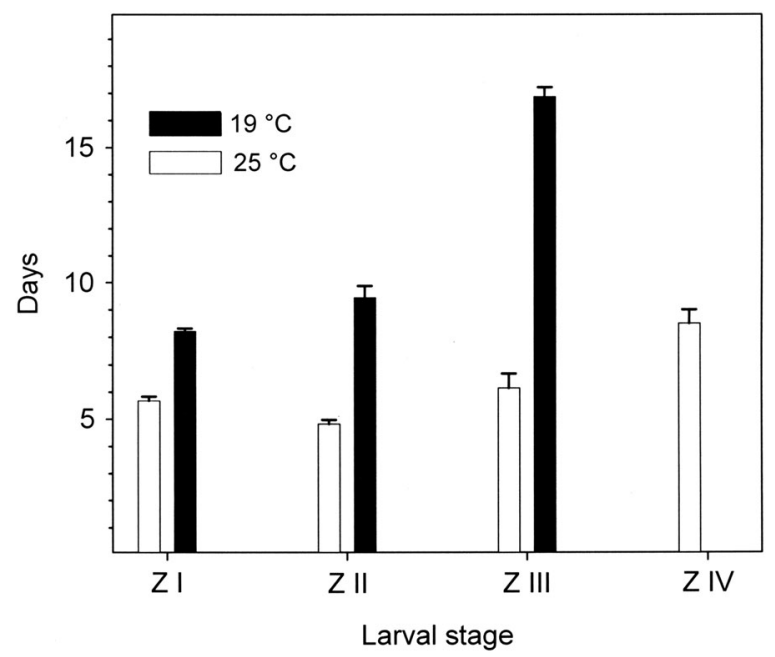

Figure 6. Mean duration of different zoeal stages of Afropinnotheres monodi reared at 19 and $25^{\circ} \mathrm{C}$.

Pleon (Figure 4H): Six pleonites, setation as shown. Pleopods (Figure 4I,J): Biramous, present on pleonites 2-5. Endopod of pleopods 2-4 with 3 cincinuli and exopod with 8 long terminal plumose natatory setae. Endopod of pleopod 5 with 2 cincinuli and exopod with 6 long terminal plumose natatory setae. Uropods absent.

Telson (Figure $4 \mathrm{H}$ ): Rounded with 2 pairs of simple setae on terminal margin.

\section{Molecular study}

The $16 \mathrm{~S}$ mtDNA sequences obtained from adults and larvae of Afropinnotheres monodi consist of $552 \mathrm{bp}$ (excluding the primers). All sequences fit $100 \%$, and only one haplotype is shared for all specimens analyzed. Pairwise genetic distances between $A$. monodi and the other lberian pinnotherid species, Pinnotheres pisum (GenBank AM180694, 553 bp) and Nepinnotheres pinnotheres (GenBank: EU935001, 550 bp), indicate stronger differences with $P$. pisum (0.991) than with N. pinnotheres (0.056). Furthermore, studying the mutation rate of these sequences with respect to those of $A$. monodi, 50 mutations $(9.05 \%$ divergence rate) are observed in $P$. pisum and 30 mutations (5.45\% divergence rate) in $N$. pinnotheres. These clear differences allow accurate identification of the three species based on this molecular marker.

\section{Effects of temperature on larval development}

As observed both in specimens recovered from the field (natural plankton) and those in laboratory cultures, the larval development of Afropinnotheres monodi consists of four zoea stages and one megalopa.
In reared larvae, the duration of each zoea development stage, and its temporal pattern of mortality, varied depending on the temperature (Figure 5). The time from larval hatching to the megalopa stage was around 25 days at $25^{\circ} \mathrm{C}$, and longer than 40 days at $19^{\circ} \mathrm{C}$; concurrently, $25 \%$ of zoeae reared at $25^{\circ} \mathrm{C}$ and $19^{\circ} \mathrm{C}$ were still alive after 18 and 33 days post-hatching, respectively.

Mean $( \pm \mathrm{SE})$ duration of each zoea stage fluctuated between: $5.68 \pm 0.16$ days at $25^{\circ} \mathrm{C}$ and $8.20 \pm 0.09$ days at $19^{\circ} \mathrm{C}$ for Zoea l; $4.83 \pm 0.16$ days at $25^{\circ} \mathrm{C}$ and $9.46 \pm$ 0.42 days at $19^{\circ} \mathrm{C}$ for Zoea II; $6.14 \pm 0.55$ days at $25^{\circ} \mathrm{C}$ and $16.88 \pm 0.35$ days at $19^{\circ} \mathrm{C}$ for Zoea III; and $8.50 \pm$ 0.70 days at $25^{\circ} \mathrm{C}$ for Zoea IV (Figure 6). For each zoea stage, the developmental duration was significantly shorter for larvae reared at $25^{\circ} \mathrm{C}$ than for those reared at $19^{\circ} \mathrm{C}(P<0.05)$. No significant differences in development duration were observed between Zoea I, II and III reared at $25^{\circ} \mathrm{C}$, whereas larvae spent a significantly longer period as Zoea IV at this temperature; similarly, there was no significant difference between the development duration of Zoea I and II stages of larvae reared at $19^{\circ} \mathrm{C}$, whereas they spent a longer period as Zoea III $(P<0.05)$.

The mean mortality rate of each zoea stage was always lower for larvae reared at $25^{\circ} \mathrm{C}$ than at $19^{\circ} \mathrm{C}$ (Table I), although such differences were not statistically significant $(P>0.05)$. An increased pattern of mortality rates was observed from early to older zoea stages at both tested temperatures. Namely, differences in mortality among different zoea stages at each temperature were statistically significant $(P<0.01)$, except between Zoea I and II and between Zoea III and IV reared at 19 and $25^{\circ}$ $C$, respectively $(P>0.05)$. In addition, there was a higher mortality $(P<0.05)$ between slower-growing specimens 
Table I. Mean mortality (\%) of different larval stages at 19 and $25^{\circ} \mathrm{C}$, as well as mortality for larvae with rapid (RD, below mean stage duration) and slow (SD, above mean stage duration) development. In bold: zoeal mean mortalities that were significantly higher (chi-squared test, $P<0.05$ ) at $19^{\circ} \mathrm{C}$ than at $25^{\circ} \mathrm{C}$; and SD mortalities that were significantly higher than the corresponding RD. md: missing data.

\begin{tabular}{lcccccc}
\hline & \multicolumn{1}{c}{$19^{\circ} \mathrm{C}$} & & \multicolumn{2}{c}{$25^{\circ} \mathrm{C}$} \\
\cline { 2 - 4 } & Mean & RD & SD & & Mean & RD \\
\hline Z I & $\mathbf{3 3 . 0 0}$ & 20.97 & $\mathbf{5 2 . 6 3}$ & 21.00 & 0.00 & SD \\
Z II & $\mathbf{5 5 . 0 0}$ & 50.00 & 58.82 & 41.8 & $\mathbf{5 1 . 2 2}$ \\
Z III & $\mathbf{7 8 . 4 0}$ & 86.36 & 66.67 & 69.6 & $\mathbf{5 1 . 3 5}$ \\
Z IV & md & md & md & 85.7 & 43.75 & 83.89 \\
\hline
\end{tabular}

(development duration above the mean) for Zoea I at both temperatures, and for Zoea II and III at $25^{\circ} \mathrm{C}$ (Table I).

\section{Morphological comparison of plankton and reared larvae}

A total of 25 zoeae of various stages, and 13 megalopae recovered from the plankton were identified by comparison with their 16S mtDNA sequences, and once morphological characters were established the rest of zoeae (37 specimens) were identified by morphology. All sequences obtained fit $100 \%$ with the $16 \mathrm{~S} \mathrm{mtDNA}$ sequence of adult specimens of Afropinnotheres monodi, and any others corresponded to other native pinnotherids (Pinnotheres pisum and Nepinnotheres pinnotheres). All these specimens were used for size measurements and for morphological comparison. No differences in size or morphology (including setation patterns) were found between plankton and laboratory-reared larvae and for this reason larvae from both origins were used in the descriptions.

\section{Discussion}

\section{Dispersal capability of Afropinnotheres monodi}

Among the few complete larval development records known for Pinnotherinae s.s. the number of larval stages varied from two to four, although three was the most frequent (Palacios-Theil et al. 2009). Afropinnotheres monodi with four zoea stages may be considered to have an extended development, which represents an advantage for dispersal success. In fact, although all zoea stages of $A$. monodi have been collected in estuarine waters, pointing to a possible retention mechanism, the species has also been found in bivalves that inhabit breakwaters and intertidal rocky shores (Drake et al. 2014), suggesting a partial larval exportation out of the most sheltered estuarine habitats.

The global duration of the planktonic phase also plays a relevant role in species dispersal. The duration of the larval development of decapod crustaceans is greatly dependent on temperature (Dawirs 1979;
Lárez et al. 2000; Anger et al. 2003; Barría et al. 2005). Indeed, a $6^{\circ} \mathrm{C}$ decrease in the average temperature of larval cultures of the African pea crab A. monodi seems to double the time spent by individuals in its most dispersive zoeal phase (Figure 1). In the study area, coastal seawater temperatures follow a clear seasonal pattern, with monthly mean temperatures between $\approx 15 \pm 1^{\circ} \mathrm{C}$ in January-February and $\approx 25 \pm$ $1^{\circ} \mathrm{C}$ in July-August (Navarro \& Ruiz 2006; GarcíaLafuente et al. 2012); similarly, the lowest chlorophyll a concentrations are observed in winter, whereas the chlorophyll a maximum appears in spring followed by a second bloom either in summer or autumn (Establier et al. 1990; Navarro \& Ruiz 2006). Accordingly, although larval stages and ovigerous females of A. monodi were found all the year round in the Bay of Cádiz, an autumnal decrease in the reproductive activity has been observed (Drake et al. 1998, 2014). The temperatures used in the larval cultures in this study corresponded to both extremes of the temperature range during the period of maximal larval density of $A$. monodi in the field. Thus, as suggested for other decapod crustaceans from temperate areas (Dawirs 1979; Lindley 1990), we hypothesize that the duration of the planktonic phase of $A$. monodi in the studied area is modulated by temperature and, consequently, its dispersal capacity follows a seasonal pattern. Thus, a higher recruitment of new individuals to parental populations would be expected during the warmest summer, and a higher dispersal to new locations during the rest of the year.

Food availability and suitability are other factors affecting the duration of larval development (Anger 2001; D'Urban Jackson et al. 2014). Artemia nauplii have been successfully used as larval food for some brachyurans (Dawirs 1979; Anger 1983, 1991; Gonçalves et al. 1995; Barría et al. 2005). Because the small size of A. monodi larvae did not permit the use of Artemia nauplii as food, they were fed with rotifers that were pre-fed with algae. At the tested temperatures, the high global larval mortality and the higher mortality rate observed for larvae with slower developing growth (unhealthy larvae) may indicate that rotifers 
and algae were not the most suitable food for rearing pea crab larvae. However, algae and concentrated plankton were successfully used to feed larvae of other pinnotherid species (Sandoz \& Hopkins 1947; Atkins 1955). Furthermore, zoea mortality rates shown in this study were lower than those derived from available information on $A$. monodi zoea abundance in the studied area: zoea IV represented $0.2 \%$ and $1.1 \%$ of A. monodi zoea collected when the mean water temperature was $24.9^{\circ} \mathrm{C}$ (July) and $19.3^{\circ} \mathrm{C}$ (October), respectively (derived from data published in Drake et al. 1998). Mortality could be selectively removing the less-fit individuals of the population in the field, and as a result larval duration of survivors could be slightly shorter than that estimated under culture conditions (Dickey-Collas et al. 2000).

Some pinnotherids parasitize commercially exploited bivalves (Silas \& Alagarswami 1967; Sun et al. 2006; Mena et al. 2014), with a significant loss of production detected in some shellfish farms (Trottier et al. 2012). As males and females of Afropinnotheres monodi display an asymmetrical use of different bivalve hosts, the strongest infestation by this pea crab was expected to be found in shellfish exploitations located where their various hosts coexist; that is, in sheltered waters such as bays, inlets, rías and harbours (Drake et al. 2014). Furthermore, as this is an African species that seems to be in a clear northward expansion, under the current scenario of increasing temperature, it could represent a threat to European bivalve aquaculture in the near future.

\section{Larval morphology}

The larval morphology of Afropinnotheres monodi is, in general terms, similar to that of other Pinnotherinae s.s. However, the setation pattern of the sternum of the megalopa is a feature never described before for the Pinnotherinae s.s.; therefore, a comparison with other species was not possible. Because this is a useful character for intrageneric comparison (Marco-Herrero et al. 2012) it has been described here. Another interesting feature is the setation of the ventral margin of the cephalothorax, and A. monodi has four and five setae in Zoea III and IV, respectively. This setation has only been described in zoeae of three other Pinnotherinae (Pinnotheres pisum, Viridotheres gracilis (Bürger, 1895) and Nepinnotheres pinnotheres), and in all these cases marginal setae appear in Zoea II and the subsequent stages. In A. monodi the first seta is highly plumose, similar to the 'anterior' seta previously described and which are typical of majid zoeae (Clark et al. 1998).

A first zoea stage from plankton samples of the Selvagens Islands was tentatively attributed to $A$. monodi by Lindley et al. (2002). The brief description, the position of lateral spines of the cephalothorax, the bifurcated telson, and the general illustration clearly indicates that this larva does not belong to A. monodi, and not even to any other Pinnotheridae.

The description of the first zoea stage of Afropinnotheres larissae (Machkevsky, 1992) by Machkevsky (1999) is brief and incomplete. Thus, differences in setation pattern with respect to the first zoea of $A$. monodi should be attributed to mistakes or overlooked setae, rather than to real intrageneric differences. The general morphology clearly resembles that of A. monodi, although the dorsal, rostral and lateral spines are shorter and the ratio between dorsal and rostral spine lengths is smaller.

Larval development of the two native species from Iberian waters, Nepinnotheres pinnotheres and P. pisum, was described by Atkins (1955). The zoea stages of $N$. pinnotheres (as Pinnotheres veterum) and $P$. pisum were also previously briefly described by Lebour (1928), and the first zoea of $P$. pisum later by Rice (1975). The four zoea stages of $A$. monodi are easily distinguished from those of $P$. pisum by the presence of a well-developed dorsal spine on the

Table II. Main meristic and morphological differences between zoeal and megalopa stages of Afropinnotheres monodi, Nepinnotheres pinnotheres and Pinnotheres pisum. Abbreviations: DS, dorsal spine; (-), absent; (+), present; F, flagellum; seg. number of segments.

\begin{tabular}{|c|c|c|c|}
\hline & Afropinnotheres monodi & Nepinnotheres pinnotheres & Pinnotheres pisum \\
\hline Reference & Present study & Atkins (1955) & Atkins (1955) \\
\hline No. zoeal stages & 4 & 2 & 4 \\
\hline \multicolumn{4}{|l|}{ Zoea } \\
\hline Cephalothoracic DS & $(+)$ & $(+)$ & $(-)$ \\
\hline Z I pereiopods & $(-)$ & Buds & $(-)$ \\
\hline Z I pleopods & $(-)$ & Buds & $(-)$ \\
\hline Z II pereiopods & $(-)$ & Elongated Buds & $(-)$ \\
\hline Z II pleopods & $(-)$ & Elongated Buds & $(-)$ \\
\hline \multicolumn{4}{|l|}{ Megalopa } \\
\hline Antennular F seg. & 4 & 4 & 1 \\
\hline Antennal F seg. & 3 & 2 & 3 \\
\hline No. pleonites & 6 & 6 & 5 \\
\hline
\end{tabular}


cephalothorax of the former species (see Table II). Although N. pinnotheres has well-developed dorsal, rostral and lateral spines on the cephalothorax, as in A. monodi, N. pinnotheres has only two zoea stages. Therefore, N. pinnotheres zoeae I and II show characters of more advanced stages like pereiopods and pleopod buds on the Zoea I, and a mandibular palp in the Zoea II.

Megalopae of $N$. pinnotheres can be easily differentiated from those of $A$. monodi and $P$. pisum by having an antennal flagellum with only two segments instead of the three in the other two species (see Table II). Megalopae of $P$. pisum can be distinguished from those of $A$. monodi by: the second segment of the antennal flagellum of $P$. pisum without setae, whereas those of $A$. monodi present three long setae; the antennular flagellum is unsegmented in $P$. pisum and four-segmented in $A$. monodi; the pleon of P. pisum has only five pleonites and that of $A$. monodi six pleonites.

\section{Conclusion}

As the dispersal capability of Afropinnotheres monodi seems to be modulated by temperature, we hypothesize that higher recruitment to parental populations should occur during the warmest summer, while higher dispersal to new locations should take place during the rest of the year. This temperature-related feature could facilitate a faster northward expansion of $A$. monodi, and consequently, the infestation of European bivalve aquaculture installations by this pea crab in the near future. Thus, the information provided on the morphology of larval stages and on the genetic marker may be of use in establishing an early alert for detection of this African species in more northern European locations. Nevertheless, a long-term monitoring of seasonal larval abundance patterns in the area is needed to confirm the proposed hypothesis.

\section{Acknowledgements}

We want to thank the 'Real Club Nautico' of Puerto Santa María (Cádiz, Spain) for kindly allowing us to use their facilities. We are especially grateful to Reyes Sánchez García and Ainhoa Olaguer-Feliú, who helped in collecting the larvae, and Carlos Sánchez Nieto for his assistance in the laboratory work. Thanks are due to the Translations group and especially to Alicia Moguilevsky for revision and correction of English. Three anonymous reviewers, the subject editor Matz Berggren and the editor Franz Uiblein provided useful comments and corrections that clearly improved the manuscript.

\section{Disclosure statement}

No potential conflict of interest was reported by the authors.

\section{Funding}

The research was carried out within the framework of the projects MEGALOPADN [CGL2009-11225], 'Transporte y reclutamiento larvario de crustáceos bentónicos litorales: importancia de los agentes forzadores costeros y regimen mareal' [CTM2005-00024/MAR] and AFROBIV [CGL201453557-P], co-financed by the 'Ministerio de Economía y Competividad (MINECO)' Spanish Plan R+D+l and ERDF, European Union. Elena Marco-Herrero acknowledges a pre-doctoral FPI Fellowship supported by MINECO [BES-2010-033297].

\section{References}

Anger K. 1983. Temperature and the larval development of Hyas araneus L. (Decapoda, Majidae); extrapolation of laboratory data to field conditions. Journal of Experimental Marine Biology and Ecology 69:203-15.

Anger K. 1991. Effects of temperature and salinity on the larval development of the Chinese mitten crab Eriocheir sinensis (Decapoda: Grapsidae). Marine Ecology Progress Series 72:103-10.

Anger K. 2001. The biology of decapod crustacean larvae. Crustacean Issues 14:1-420.

Anger K, Thatje S, Lovrich G, Calcagno J. 2003. Larval and early juvenile development of Paralomis granulosa reared at different temperatures: tolerance of cold and food limitation in a lithodid crab from high latitudes. Marine Ecology Progress Series 253:243-51.

Atkins D. 1955. The post-embryonic development of British Pinnotheres (Crustacea). Proceedings of the Zoological Society of London 124:687-715.

Barría EM, Jara CG, Paschke KA. 2005. La temperatura como factor de variabilidad en el desarrollo y morfología de larvas zoeas de Acanthocyclus hassleri Rathbun (Decapoda, Brachyura, Atelecyclidae) cultivadas en laboratorio. Investigaciones Marinas 33:25-41.

Becker C, Türkay M. 2010. Taxonomy and morphology of European pea crabs (Crustacea: Brachyura: Pinnotheridae). Journal of Natural History 44:1555-75.

Clark PF, Calazans DK, Pohle GW. 1998. Accuracy and standardization of brachyuran larval descriptions. Invertebrate Reproduction \& Development 33:127-44.

Dawirs RR. 1979. Effects of temperature and salinity on larval development of Pagurus bernhardus (Decapoda, Paguridae). Marine Ecology Progress Series 1:323-29.

Dickey-Collas M, McQuaid N, Armstrong MJ, Allen M, Briggs RP. 2000. Temperature-dependent stage durations of Irish Sea Nephrops larvae. Journal of Plankton Research 22:749-60.

Drake P, Arias AM, Rodríguez A. 1998. Seasonal and tidal abundance patterns of decapod crustacean larvae in a shallow inlet (SW Spain). Journal of Plankton Research 20:585-601.

Drake P, Marco-Herrero E, Subida MD, Arias AM, Cuesta JA. 2014. Host use pattern of the pea crab Afropinnotheres monodi: potential effects on its reproductive success and 
geographical expansion. Marine Ecology Progress Series 498:203-15.

D'Urban Jackson T, Torres G, Giménez L. 2014. Survival and development of larvae of two decapod crustaceans under limited access to prey across a thermal range. Journal of Plankton Research 36:1476-87.

Establier R, Blasco J, Lubián LM, Gómez-Parra A. 1990. Phytoplankton and hydrography of the Bay of Cadiz (SW Spain) from April 1986 to December 1988. Scientia Marina 54:203-09.

García-Lafuente J, Delgado J, Navarro G, Calero C, DíezMinguito M, Ruiz J, et al. 2012. About the tidal oscillations of temperature in a tidally driven estuary: the case of Guadalquivir estuary, southwest Spain. Estuarine, Coastal \& Shelf Science 111:60-66.

Gonçalves F, Ribeiro R, Soares AMVM. 1995. Laboratory study of effects of temperature and salinity on survival and larval development of a population of Rhithropanopeus harrisii from the Mondego River estuary, Portugal. Marine Biology 121:639-45.

Lárez MB, Palazón-Fernández JL, Bolaños CJ. 2000. The effect of salinity and temperature on the larval development of Mithrax caribbaeus Rathbun, 1920 (Brachyura, Majidae) reared in the laboratory. Journal of Plankton Research 22:1855-69.

Lebour MV. 1928. The larval stages of the Plymouth Brachyura. Proceedings of the Zoological Society of London 98:473-560.

Lindley JA. 1990. Regressions for estimating development times of the pelagic larvae of Paguridae and Porcellanidae. Journal of Plankton Research 12:673-78.

Lindley JA, Hernández F, Tejera E, Jiménez S. 2002. An unusual pinnotherid zoea attributed to Afropinnotheres monodi Manning, 1993 (Brachyura: Pinnotheroidea) from the Selvage Islands (Eastern Atlantic Ocean). Bocagiana 205:1-5.

Machkevsky VK. 1992. A new crab species, Pinnotheres larissae sp. n. (Decapoda Brachyura Pinnotheridae) from the mangrove oyster Crassostrea tulipa (Bivalvia, Ostreidae) of West Africa. Russian Journal of Arthropoda Research 1:83-88.

Machkevsky VK. 1999. The morphology of the crab Afropinnotheres larissae (Machkevsky, 1992) zoeae and the ways of infestation with pea crab of the mangrove oyster. Ekologiya Morya 49:63-68. (in Russian)

Manning RB. 1993. West African pinnotherid crabs, subfamily Pinnotherinae (Crustacea, Decapoda, Brachyura). Bulletin du Muséum National d'Histoire Naturelle 15:125-78.

Marco-Herrero E, Rodríguez A, Cuesta JA. 2012. Morphology of the larval stages of Macropodia czernjawskii (Brandt, 1880) (Decapoda, Brachyura, Inachidae) reared in the laboratory. Zootaxa 3338:33-48.

Marco-Herrero E, Torres AP, Cuesta JA, Guerao G, Palero F, Abelló P. 2013. The systematic position of Ergasticus (Decapoda, Brachyura) and allied genera, a molecular and morphological approach. Zoologica Scripta 42:427-39.
Marco-Herrero E, González-Gordillo Jl, Cuesta JA. 2014. Morphology of the megalopa of the mud crab, Rhithropanopeus harrisii (Gould, 1841) (Decapoda, Brachyura, Panopeidae), identified by DNA barcode. Helgoland Marine Research 68:201-08.

Mena S, Salas-Moya C, Wehrtmann IS. 2014. Living with a crab: effect of Austinotheres angelicus (Brachyura, Pinnotheridae) infestation on the condition of Saccostrea palmula (Ostreoida, Ostreidae). Nauplius 22:151-58.

Navarro G, Ruiz J. 2006. Spatial and temporal variability of phytoplankton in the Gulf of Cádiz through remote sensing images. Deep-Sea Research II 53:1241-60.

Olaguer-Feliú AO, Flores AAV, Queiroga H, González-Gordillo Jl. 2010. Shelf and estuarine transport mechanisms affecting the supply of competent larvae in a suite of brachyuran crabs with different life histories. Marine Ecology Progress Series 410:125-41.

Palacios-Theil E, Cuesta JA, Campos E, Felder DL. 2009. Molecular genetic re-examination of subfamilies and polyphyly in the family Pinnotheridae (Crustacea: Decapoda). In: Martin J, Crandall K, Felder D, editors. Decapod Crustacean Phylogenetics. Boca Raton: CRC Press, p 447-72.

Pfeiffer-Hoyt AS, McManus MA. 2005. Modeling the effects of environmental variability on Balanus glandula larval development. Journal of Plankton Research 27:1211-28.

Rice AL. 1975. The first zoeal stages of Cancer pagurus L., Pinnotheres pisum (Pennant) and Macrophthalmus depressus Rüppel (Crustacea, Decapoda, Brachyura). Bulletin of British Museum, Natural History (Zoology) 28:237-47.

Sandoz M, Hopkins SH. 1947. Early life history of the oyster crab, Pinnotheres ostreum (Say). The Biological Bulletin 93:250-58.

Silas EG, Alagarswami K. 1967. On an instance of parasitisation by the pea-crab (Pinnotheres sp.) on the back-water clam (Meretrix casta (Chemnitz)) from India, with a review of the work on the systematics, ecology, biology and ethology of pea crabs of the genus Pinnotheres Latreille. Proccedings of the Marine Biological Association of India (Symposium Series 2) 3:1161-227.

Subida MD, Arias AM, Drake P, García Raso JE, Rodríguez A, Cuesta JA. 2011. On the occurrence of Afropinnotheres monodi Manning, 1993 (Decapoda: Pinnotheridae) in European waters. Journal of Crustacean Biology 31:367-69.

Sun W, Sun S, Yuqi W, Baowen Y, Weibo S. 2006. The prevalence of the pea crab, Pinnotheres sinensis, and its impact on the condition of the cultured mussel, Mytilus galloprovincialis, in Jiaonan waters (Shandong Province, China). Aquaculture 253:57-63.

Trottier O, Walker D, Jeffs AG. 2012. Impact of the parasitic pea crab Pinnotheres novaezelandiae on aquacultured New Zealand green-lipped mussels, Perna canaliculus. Aquaculture 344-9:23-28. 